\title{
Az online térben bekövetkező zaklatások lehetséges okai, dinamikai jellegzetességei és megoldási lehetőségei
}

\author{
Possible Causes, Dynamic Characteristics \\ and Possible Solutions to Cyberbullying
}

A 21. században a technológiai újítások fénykorát éljük. Az online tér nagyban megkönnyíti mindennapjainkat, ugyanakkor számos elönye mellett a sötét oldalát is kénytelenek vagyunk megismerni. Nem kell a legdrasztikusabb cselekményekre gondolni ahhoz, hogy találkozzunk az internet veszélyeivel: elég csupán, ha zaklatásnak vagyunk kitéve a közösségi média egyes platformjain. Az online zaklatás, más néven cyberbulylying olyan, agresszív és szándékosan ismétlödő cselekvés, amelyet egy egyén vagy csoport hajt végre elektronikus eszközök alkalmazásával (kép, videó eljuttatásával, telefonhivással, e-mailek küldésével, weboldalak és egyéb üzenetküldő programok használatával), s amellyel szemben az áldozat gyakran védtelen. Fontos feladat azonosítani az elkövetőket és feltárni az egyes zaklatások mögött meghúzódó dinamikai folyamatokat. Az elkövetők személyiségelemzése révén felkutatásuk és azonosításuk felgyorsulhat, az áldozatok jó esetben segítséget kapnak az átélt traumával való megküzdéshez és a reziliencia tudatos formálásával kapcsolatban, továbbá hatékony preventiv és interventiv módszerek kidolgozása is megvalósulhat.

Kulcsszavak: cyber, online zaklatás, cyberbullying, elkövetök, áldozatok, csoportdinamika, pszichológiai magyarázatok, protektív faktorok

In the $21^{\text {th }}$ century, we are living in the heydays of technological innovations. The Internet makes our everyday lives a lot easier, but in addition to its many benefits, we also need to get to know its dark side. We don't have to think about the most drastic acts to face the dangers of the Internet: it's enough to just be harassed on various social media platforms. Online harassment, also known as cyberbullying, is an aggressive

Szakügyintéző, Budapesti Rendőr-főkapitányság, V. Kerületi Rendőr-kapitányság, Vizsgálati Osztály, Gazdaságvédelmi Alosztály, e-mail: ErdelyiAk@budapest.police.hu 
and repetitive intentional act committed by an individual or group using electronic means (sending pictures or videos, making phone calls, sending emails, using websites and other messaging programs) against the victim who is often unprotected. It is an important task to identify the perpetrators and to explore the dynamic processes behind each harassment. Personality and behaviour analysis of perpetrators can speed up their tracing and identification, help victims cope with the trauma they have experienced and consciously shape resilience, and develop effective preventive and interventional methods.

Keywords: cyber, online harassment, cyberbullying, perpetrators, victims, group dynamics, psychological explanations, protective factors

\section{Bevezetés}

Napjainkat áthatják a technológiai újítások. Még fel sem dolgoztuk, pontosabban nem is frissítettük a legutóbbi fejlesztést, máris van egy újabb verzió. A számítástechnikai fejlesztések és az információs rendszerek szerepe napjainkban felértékelődött - a pandémia időszakában nem csak ennek pozitív aspektusai, hiszen a bünözés is jelentős mértékben áthelyeződött a kibertérbe. Az internethasználat során gyakran felmerül a kérdés: mi jó és hasznos, és mi az, ami már egyáltalán nem minősül annak. Sok előnye mellett - mint például a gyors információáramlás, a kapcsolatépítés és kapcsolattartás, a szórakozást biztosító website-ok - a kevésbé pozitív, sőt gyakran negatív tényezők is egyre nagyobb szerepet kapnak, főleg a Z generáció életében. A fejlődés számos ígéretes dologhoz segített hozzá bennünket, azonban itt is megtaláljuk az előnyök mellett a hátrányokat is, amelyek közé nem pusztán az addiktív állapot kialakulása, az önbizalom és önértékelés diszfunkcionalitása tartozik, de idesorolható számos jogi kérdést is felvető (bűn)cselekmény: az internetes pedofília, a személyes adatokkal való visszaélés, az online gyülöletbeszéd és még lehetne folytatni a sort.

Különösen nagy hangsúlyt kap a zaklatás „21. századi” formája, a cyberbullying, azaz az online, elektronikus eszközök alkalmazásával történő zaklatás. Számos empirikus kutatás foglalkozott már ennek kérdéseivel, és igyekeztek meghatározni a cselekmény mentális mozgatórugóit, megrajzolni a személyiségprofilokat, és megfelelő prevenciós és intervenciós stratégiákat kidolgozni. ${ }^{2}$ Jelen munkám célja nem az internet és az internetezés ellen irányuló tanulmány; sokkal inkább egy összefoglaló készítése, amelyben áttekintem e zaklatási mód típusait, a motivációkat, és összegzem az ismert és a lehetséges prevenciós megközelítéseket.

Lásd összefoglalóan Domonkos Katalin: Cyberbullying. Zaklatás elektronikus eszközök használatával. Alkalmazott Pszichológia, 14. (2014), 1. 59-70. 


\section{Cyberbullying - definíciók}

A negatív cselekmények összefoglaló megnevezésére alkották meg az elektronikus zaklatás definícióját, amely megjelenhet bántó és gyűlöletkeltő tartalmak formájában, nem kívánatos üzenetek és tartalmak küldéseként, valamint megszégyenítésre alkalmas videók és képek megosztása gyanánt. A kutatók első ízben az ezredfordulót követő években kezdtek foglalkozni a kérdéssel. Az azóta eltelt idő során a cyberbullyingra számtalan definíció született, egyre többet írnak megjelenési formáiról és a már vizsgált területeiről. Az alábbiakban az egyes definíciós kontextusokat tekintem át:

1. táblázat

\begin{tabular}{|l|l|}
\hline Patchin és Hinduja, 2006 & $\begin{array}{l}\text { Internet vagy mobiltelefon használatával elkövetett ismételt károkozás } \\
\text { különböző típusú (szövegi, képi) tartalom küldésével. }\end{array}$ \\
\hline Smith és munkatársai, 2008 & $\begin{array}{l}\text { Olyan agresszív és ismétlődő szándékos cselekvés, amelyet egy egyén } \\
\text { vagy csoport hajt végre elektronikus eszközök alkalmazásával, s amellyel } \\
\text { szemben az áldozat gyakran védtelen. }\end{array}$ \\
\hline Basley, 2009 & $\begin{array}{l}\text { Egy egyén vagy csoport által követett ellenséges és szándékos viselkedés, } \\
\text { amelyet kommunikációs eszközök által hajtanak végre annak céljából, hogy } \\
\text { másnak kárt okozzanak. }\end{array}$ \\
\hline Slonje, 2012 & $\begin{array}{l}\text { SMS, kép, videó eljuttatásával, telefonhívással, e-mailek küldésével, } \\
\text { weboldalak és egyéb üzenetküldő programok használatával megvalósuló } \\
\text { cselekmény. }\end{array}$ \\
\hline
\end{tabular}

Forrás: Domonkos (2014): i. m.

Jól látható, hogy a zaklatásra jellemző motívumok az online zaklatás definiálása során is helyet kapnak: a szándékosság, az ismétlődés és a tudatosság tehát az a három kulcsfogalom, amelynek meghatározását és detektálását követően adott eseménysort zaklatásként azonosítunk.

Egyes kutatók a zaklatásnak olyan jelzőket tulajdonítanak, mint az ismételt, negatív verbális és fizikai viselkedés, az informatikai és egyéb kommunikációs eszközök által folytatott cselekvés. ${ }^{3} \mathrm{Az}$ egyén vagy csoport által végrehajtott ellenséges viselkedés a legkülönbözőbb módokon valósulhat meg: mobilhívások, e-mailek, blogok adják az online zaklatás eszköztárát. Módszereit vizsgálva hasonló differenciáltságot fedezünk fel: az ellenséges viselkedés megnyilvánulhat hazugság, becsapás, rágalmazás által. Gyakori az anonimitás megőrzése, a másik személy bőrébe bújás (vagyis amikor magunkat egy másik, létező személyként azonosítjuk, és az ő nevében osztunk meg valótlan állításokat), a mások fényképének engedély nélküli felhasználása és terjesztése, a fenyegetés és megfélemlítés, valamint az ugratás.

Látható továbbá, hogy valamennyi definícióban központi szerephez jut a cselekmény időszakos, többszöri előfordulása, az életvitelben lehetségesen bekövetkező negatív változások, ${ }^{4}$ ami érthető, hiszen zaklatásról csak ezek megállapítását

Tolga Aricak et al.: Bullying, Cyberbullying and Suicide. Cyberpsychology \& Behavior, 11. (2008), 3. $253-261$. Domonkos Katalin - Ujhelyi Adrienn: Az online zaklatás médiareprezentációja. Neveléstudomány, (2015), 1. 77-92. 
követően beszélhetünk. Valamennyi elméletalkotó kiemeli, hogy cyberbullying során az infokommunikációs eszközök alkalmazása felértékelődik, szerepüket a felhasználók felülreprezentálják.

\section{3. Átfedés az offline és az online zaklatás között}

Kutatók szerint jelentős a kapcsolat és az átfedés a két típus között. Azok, akik az offline, tehát a fizikai világban elkövetők, nagyobb valószínűség szerint lesznek azzá az online világban is. Az áldozatok szemszögéből vizsgálva a kérdést szintén megállapítható, hogy azok, akik az offline térben büncselekmény áldozatai, a kibertérben is nagyobb eséllyel válnak sértetté. A cselekményekhez kapcsolódó morális érzelmek megjelenése és átélése csökken: a hagyományos zaklatási esetekben több lehetőség adódik az empátia átélésére, mint a virtuális térben (ennek okait lásd a következő fejezetben). Azok a fiatalok, akik a zaklatás mindkét típusában érintettek, inkább számolnak be depressziós időszakokról és magasabb arányban követnek el öngyilkosságot, mint azok, akik csak az egyikben áldozatok. ${ }^{5}$

Aricak és munkatársai véleménye szerint ${ }^{6}$ a zaklatások két jól elkülöníthető típus mentén azonosíthatók attól függően, hogy nyílt vagy rejtett zaklatásról van-e szó. Amennyiben a zaklatás nyílt, tehát mások bevonásával, mások előtt történik, akkor direkt zaklatásról van szó, amelynek során a zaklató olyan eszközöket használ célja elérése érdekében, mint az erőszakos viselkedés verbális kifejezése vagy a direkt fizikai abúzus, például verekedés kezdeményezése vagy a másik ugratása. Ezzel szemben az indirekt zaklatás során (rejtett zaklatáskor) az elkövető az áldozatok szociális kapcsolatait, társas interakciót semmisíti meg. Ennek érdekében pletykákat, rosszindulatú és hamis híreszteléseket kelt és terjeszt, elszeparálja, kizárja áldozatát a társas közegből. A zaklatások elkövetési módjai között a verbális (fenyegetés, ugratás), a fizikai (ütlegelés, rugdosás), illetve a manipulatív stratégiák (kiközösítés, kierőszakolás) alkalmazása gyakori.7 A bullying egy agresszív cselekvés, ilyenkor egy egyén vagy csoport direkt vagy indirekt formában abuzál másokat. ${ }^{8} \mathrm{~A}$ továbbiakban, mielőtt rátérnék a cyberbullying általános jellemzőire, fontos látni, hogy a büntetőjog hogyan kezeli a zaklatás bǔncselekményét.

\section{A zaklatás és a Btk.}

A zaklatás, hasonlóan más típusú bűncselekményekhez, törvénykönyvben rögzített bűncselekmény, amely a személy elleni erőszakos bűncselekmények kategóriájába

Domonkos (2014): i. m.

Aricak et al. (2008) i. m.

Sameer Hinduja - Justin W. Patchin: Bullying, cyberbullying and suicide. Archives of Suicide Research, 14. (2010), 206-221.

Rosario Ortega-Ruiz et al.: The Emotional Impact on Victims of Traditional Bullying and Cyberbullying. Journal of Psychology, (2009), 4. 197-204. 
tartozik. A Büntető Törvénykönyvről szóló 2012. évi C. törvény a 222. §-ban rögzíti a zaklatás törvényi tényállását. Ennek értelmében:

„Aki abból a célból, hogy mást megfélemlítsen, vagy más magánéletébe, illetve mindennapi életvitelébe önkényesen beavatkozzon, őt rendszeresen vagy tartósan háborgatja, ha súlyosabb búncselekmény nem valósul meg, vétség miatt egy évig terjedő szabadságvesztéssel büntetendő." ${ }^{9}$

A (2) bekezdés folytatólagosan így fogalmaz:

„Aki félelemkeltés céljából

a) mást vagy rá tekintettel hozzátartozóját személy elleni erőszakos vagy közveszélyt okozó büntetendő cselekmény elkövetésével megfenyeget, vagy

b) azt a látszatot kelti, hogy más életét, testi épségét vagy egészségét sértő vagy közvetlenül veszélyeztető esemény következik be, vétség miatt két évig terjedő szabadságvesztéssel büntetendő."10

A (3) bekezdésben - hasonlóan, mint a legtöbb büncselekményt illetően - a törvénykönyv minősített eseteket fogalmaz meg, amelyek értelmében:

„Aki a zaklatást

a) házastársa, volt házastársa, élettársa vagy volt élettársa sérelmére,

b) nevelése, felügyelete, gondozása vagy gyógykezelése alatt álló személy sérelmére,

c) hatalmi vagy befolyási helyzetével visszaélve, illetve

d) hivatalos személy sérelmére, hivatali tevékenységével össze nem egyeztethető helyen vagy időben követi el, az (1) bekezdésben meghatározott esetben két évig, a (2) bekezdésben meghatározott esetben büntett miatt három évig terjedő szabadságvesztéssel büntetendő."11

Mint látjuk, a jogalkotó itt is él azzal a lehetőséggel, hogy úgynevezett minősített eseteket fogalmazzon meg a zaklatás tényállásával kapcsolatban, ezzel lehetőséget adva a büncselekmény súlyosabban történő szankcionálásához. A jogalkotó ebben a tényállásban úgy fogalmaz, hogy a jogi tárgy (= a védendő érték) a személy magánélethez, mindennapi életviteléhez való joga, valamint az élet, egészség és testi épség sértetlensége. Elkövetési tárgya (= amire vagy akire nézve a büncselekményt elkövetik, vagyis ami vagy aki a büncselekmény sértettje) és elkövetője bárki lehet - erre az aki személyes névmással utalva.

Az elkövetési magatartás az első fordulatban a más életébe való önkényes beavatkozás, a második fordulatban pedig a félelemkeltés. Tehát a zaklatás csak tevőlegesen elkövethető búncselekmény. Az elkövetés módja az első fordulatban 
a megfélemlítés, míg a második fordulatban az erőszakos vagy közveszélyt okozó cselekménnyel való fenyegetés.

A hazai esetszámokat tekintve ${ }^{12}$ láthatjuk, hogy 2018 II. féléve óta napjainkig összesen több mint 11 ezer eset történt meg. A legtöbb a fővárosban (1713 eset), megyei szinten az első két helyezett Borsod-Abaúj-Zemplén (1302 eset) és Pest megye (1242 eset), míg a legkevesebb eset Vas (263) és Zala megyében (223) fordult elő. Azt is látjuk, hogy több mint 4800 esetben felnőtt korúval szemben indult eljárás, és a fiatalkorúakkal szemben csupán 209 esetben foganatosítottak ilyet. A nemek megoszlásakor az a tendencia látszik, hogy többnyire férfiak követték el a büncselekményt, közülük is főként felnőtt korúak. Ami viszont a statisztikából nem látszik: milyen típusú zaklatásról van szó? Offline vagy online, esetleg mindkettő?

\section{A cyberbullying általános jellemzői}

A hazai diskurzusban is gyakran csak angol nevével illetett „cyberbullying” vizsgálata interdiszciplináris terület, mivel nem pusztán pszichológusok, hanem pedagógusok, jogi szakemberek és szociológusok is foglalkoznak a téma kérdéskörével. A nemi érintettségről nincs egységes konszenzus a kutatók között. Domonkos és Ujhelyi ${ }^{13}$ - a releváns kutatások áttekintése után - úgy vélik, hogy a zaklatás során az elkövető és az áldozat szerepeit betöltő fiatalok között jól körbejárható módon nemi eltérés van: a lányok sokkal kevesebb alkalommal válnak elkövetővé és sokkal nagyobb eséllyel válnak sértetté, mint a fiúk. Fiúk esetében mindez fordított. A tanulmányban azonban arról olvashatunk, hogy nincs összefüggés a nemek magasabb arányú érintettsége és a zaklatás között, vagyis a fiúk és a lányok egyenlő arányban válhatnak elkövetővé és áldozattá. ${ }^{14}$

Az internetes zaklatás legveszélyesebb jellemzője, hogy tartalma gyakorlatilag azonnal terjeszthetővé válik, így a sértő bejegyzéssel az áldozat újra és újra találkozik - ezzel újabb és újabb traumatizációnak és viktimizációnak válva kiszolgáltatottá -, mindez pedig az esetek többségében a nyilvánosság bevonásával zajlik. Aricak úgy fogalmaz, hogy „a számítógépek megjelenése előtt a gyerekek biztonságban érezhették magukat a szobájukban a zaklató aktusok elől, de ma már a cyberbullying képes oda is behatolni". ${ }^{15}$

Manapság a mobilinternetnek, a wifihálózatoknak és egyéb hot spotoknak köszönhetően bármikor csatlakozni tudunk a világhálóra. Ha eltévedünk, semmi gond, nem esünk kétségbe, csak megnyitjuk a Google Maps vagy a Waze alkalmazásokat, és már meg is oldottuk a problémánkat. Gyakorlatilag 0-24 órában elérhetővé váltunk. Az állandó elérhetőség, az online eltöltött idő nagy mennyisége a cyberbullying kialakulásának másik kedvező feltétele. A sértett bármikor célkeresztbe kerülhet. Kutatók szerint ez azért is veszélyes, mert nehezebbé válik az elmenekülés, és az érzelmi

Forrás: Egységes Nyomozóhatósági és Ügyészségi Bűnügyi Statisztika. 2021. 01. 23.

Domonkos-Ujhelyi (2015): i. m.

Heidi Vandebosch - Katrien van Cleemput: Cyberbullying among youngsters. Profiles of bullies and victims.

New Media \& Society, 11. (2009), 8. 1349-1371.

Aricak et al. (2008): i. m. 253. 
bevonódás sokkal megterhelőbb, mint a zaklatás offline változatában. A virtuális tér egyik hátránya az anonimitás lehetősége, ami keltheti azt a látszatot, hogy az elkövető „megússza” a felelősségre vonást, ez pedig elősegítheti a zaklató tevékenység megismétlődését. A térbeli távolság a zaklató és áldozata között szintén hozzájárul ahhoz, hogy a zaklatás gyakoribbá váljon, továbbá hatással van az empátia átélésére is: „a nonverbális jelek hiánya miatt az elkövető nem látja áldozata reakcióját, nem szembesül a zaklatás következményeivel, csökken az áldozattal való együttérzés esélye, ami növeli az ismétlődés lehetőségét és a büntudat hiányához vezet". ${ }^{16} \mathrm{Az}$ online zaklatás során az elkövető és az áldozat között több kilométer távolság is lehet, így a zaklató, ahogy Domonkos is írja, nem szembesül közvetlenül áldozatának reakciójával. Addig, amíg offline esetekben nagyobb az esély az empátia átérzésére - hiszen az elkövető látja, hogy tette milyen emocionális válaszokat váltott ki áldozatából -, az online térben jelentősen kevesebb. A hagyományos zaklatás megvalósításánál szükséges feltétel volt a fizikai közelség, a kontaktusteremtés; a zaklató és áldozat viszonylag közel tartózkodtak egymáshoz, vagyis az elkövető a reakciót közvetlenül tapasztalta meg, amely közvetlen tapasztalás elősegítette a morális érzelmek, köztük az empátia megélését. Online térben azonban a reakcióról az elkövető csak közvetetten kap visszajelzést: az általa megtettek elhárítására irányuló aktust látja mindössze (például üzenet törlése, személy letiltása vagy blokkolása), de a mögötte húzódó érzelmi töltetet nem, így a morális érzelmek kiváltódása nehezebben megy végbe.

\section{Személyiségprofilok}

\subsection{Az elkövetők személyiségrajza}

A résztvevők személyiségét áttekintve mindenekelőtt megállapíthatjuk, hogy az online agresszorokra a pszichoszociális karakterisztikumok tekintetében az alacsony elköteleződés jellemző, és gyakori, hogy fizikailag is inzultálják társaikat. Igyekeznek megszerezni a másik személy feletti kontrollt, és dominanciát gyakorolni. Általában nemcsak a kortársaikkal szemben agresszívek, hanem a felnőttek irányában is. Gyakran szegik meg az iskolai szabályokat, előírásokat - esetenként a törvénnyel is szembekerülnek. Alacsony iskolai elköteleződéssel jellemezhetők, továbbá esetükben gyakoriak a kriminalizáló aktusok (például a szerhasználat és a lopás). Általában extrovertáltak. A családjukban ritka a feléjük irányuló szülői ellenőrzés, azonban a fizikai büntetés gyakori. Csoportjuk viszonylatában (osztályon belül) központi helyet foglalnak el. Jellemzően olyan személyek, akik előzetes provokáció nélkül támadnak áldozatukra, társaiktól pedig fizikailag erőteljesebbnek érzik magukat. Önbizalmuk határtalan, szelf-percepciójuk jellemzően pozitiv irányba torzít. Énképük - én-ideáljuk - elvárt énjük között nagyfokú kongruencia figyelhető meg. Az elkövetők többsége úgy jellemezi magát, mint domináns személy, amely kijelentéssel az énképéről ad visszajelzést. Elbeszéléseik szerint azonban még nagyobb dominanciára vágynak (én-ideál),

Domonkos (2014): i. m. 62. 
sőt, úgy gondolják, hogy a domináns viselkedést mások is elvárják tőlük (elvárt én). Az elkövetővé válás az alacsony szocioökonómiai státuszt betöltő és idősebb fiatalok körében magasabb, kiindulópontjának a 10-12 éves kort jelölik meg a szakemberek. Lányok inkább a zaklatás indirekt módját választják (pletykák terjesztése, rágalmazás), míg a fiúk a nyílt és direkt formát preferálják, amely agresszív viselkedés nemcsak az iskolában nyilvánul meg, hanem otthon, vagy akár a szomszédban, sőt a közösségi oldalakon is. ${ }^{17}$

\subsection{Az áldozatok profilja}

Alacsony önértékeléssel és önbizalommal rendelkeznek, társaiknál fizikailag gyengébbek vagy annak tekintik magukat. Barátaik száma kevés, introvertált, elszigetelt személyek, akikre bizonytalanság jellemző. Interperszonális kapcsolataik lazák, osztálytársaikkal nem tudnak szoros kapcsolatot kialakítani. Nagyobb a viktimizáció esélye azoknál a fiataloknál, akik nem heteroszexuálisak; azoknál, akik több információt osztanak meg magukról a közösségi oldalakon, ugyanakkor a nem, az etnikai és faji hovatartozás, a szocioökonómiai státusz mind rizikófaktorok. Ha a szülői háttér túlságosan védelmező, a gyerekek a fejlődési és szocializációs folyamatok során nem sajátítják el a megfelelő védekező- és megküzdési stratégiákat. Szorongóvá, depresszívvé válnak, és nem ritka az önbántalmazás vagy a szuicidium sem - főleg azoknál, akik a zaklatás mindkét formájában érintettek. Tanulmányi teljesítményük romlik, az iskolához nem füzi őket szorosabb kötelék. Kevéssé népszerű személyek.

Megkülönböztetett szerepet tölt be az áldozatok egy speciális csoportja, az agreszszív áldozatok. Ők azok, akik reaktív agresszióval reagálnak egy-egy zaklató eseményre, ezzel képezve meg a zaklató áldozatok csoportját. Viselkedésük impulzív, aminek következtében a provokáló tényezőket és a fenyegetést jelentő személyeket intuitív módon rögtön ellenséges képzetekkel ruházzák fel. ${ }^{18}$

Ezen a ponton fontos néhány szót ejteni az agresszióról. Az agresszió evolúciós pszichológiai megközelítésből adaptív viselkedésmód, amely a túlélést szolgálta, szolgálja. Az agresszió szót meghallva sokakban egy negatív színezetű viselkedésről kialakult reprezentáció aktivizálódik, és az agresszióval sok esetben az erőszak asszociálódik. Azonban fontos megjegyezni, hogy létezik proszociális agresszió, ${ }^{19}$ vagyis olyan agreszszív magatartás, amely a társadalom védelme érdekében aktivizálódik - gondoljunk

Vö. Ann Frisén - Anna-Karin Jonsson - Camilla Persson: Adolescents' perception of bullying. Who is the victim? Who is the bully? What can be done to stop bullying? Adolescence, 42. (2007), 749-761; Aricak et al. (2008): i. m.; Vandebosch - Van Cleemput (2009): i. m.; Esther Calvete et al.: Cyberbullying in adolescents. Modalities and agressors' profile. Computers in Human Behavior, 26. (2010), 1128-1135; Körmendi Attila: A szemlélődők szerepe az iskolai zaklatásban. Alkalmazott Pszichológia, 14. (2014), 2. 105-121; Domonkos (2014): i. m.; Domonkos-Ujhelyi (2015): i. m.

18 Vö. Aricak et al. (2008): i. m.; Shari Kessel Schneider et al.: Cyberbullying, school bullying, and psychological distress. A regional census of high school students. American Journal of Public Health, 102. (2012), 1. 171-177; Sheri Bauman - Russel B. Toomey-Jenny L. Walker: Associations among bullying, cyberbullying, and suicide in high school students. Journal of Adolescene, 36. (2013), 341-350; Domonkos (2014): i. m.; Domonkos-Ujhelyi (2015): i. m.

19 Haller József - Fogarasi Mihály - Ivaskevics Krisztián: Agresszió és erőszakos bűncselekmények. In Haller József (szerk.): Büntettek kriminálpszichológiája. Budapest, Dialóg Campus, 2020. 17-58. 
csak a rendvédelemben dolgozó személyek magatartására, amikor egy fegyverrel felszerelkezett bűnözővel szemben intézkednek.

A stressz kezelésének egyik lehetséges formája az érzelmi alapú megküzdés, aminek során a szituációt érzelmeink irányításával próbáljuk megoldani, míg egy másik formája a problémaközpontú megküzdés, amikor az elénk táruló akadályokra és azok megszüntetésére összpontosítunk. Elmondható, hogy azok az áldozatok, akik az utóbbi stratégiát preferálták és alkalmazták a zaklatással szemben, „kevesebb egészségügyi problémáról számoltak be”, ${ }^{20}$ továbbá, hogy az életkor előrehaladtával csökken az áldozattá válás kockázata. Narratív elemzésekből kiderül, hogy az áldozatok azért váltak célponttá, mert mások voltak a többiekhez képest, például különböztek külső megjelenésükben. Néhány áldozat arról számolt be, hogy a bullying megszakadt abban a pillanatban, amikor változtattak a külsejükön, és ennek következtében már nem tértek el nagymértékben társaiktól. ${ }^{21}$

\section{Csoportdinamikai folyamatok iskolai közegben}

Amennyiben a zaklatás folyamata direkt és nyílt módon zajlik, úgy a környezet akarva-akaratlanul is belevonódik a cselekmények sorába, és különböző pozíciókat vesz fel. Három lehetséges csoportszerep azonosítható az áldozat és a zaklató személyén kívül, akik részt vesznek a folyamatban. Elsőként említendő a védelmező, aki mindent megtesz azért, hogy a sértettet megvédje és leállítsa a zaklatást, másodikként a zaklató segítői, akik mindenben támogatják őt: az offline térben ők azok, akik elfogják és leteperik az áldozatot, míg a virtuális térben megosztásokkal segítik a negatív tartalom terjedését. A harmadik csoport azután a megerősítőké. Ennek tagjai tevőlegesen nem vesznek részt a zaklatásban, azonban a zaklatónak verbális megerősítést nyújtanak, esetenként még kommentekkel is hergelve őt a kibertérben. Megjegyzendő ugyanakkor, hogy a fent említett három csoport képviselői az úgynevezett szemlélők közül kerülnek ki. Ezek a diákok formailag semlegesek, és egyik oldal mellett sem foglalnak állást, csak figyelemmel kísérik az eseményeket. Közbelépésük meggátolhatja a zaklatást, annak hiánya viszont megerősítheti a zaklató cselekvést.

A prevenció és intervenció során a cél tehát az, hogy a csoportban minél több védelmező és minél kevesebb támogató személy legyen. Egyes elméletek ennél jóval összetettebbek. Ezek a teóriák egy kontinuum mentén helyezik el a különböző szerepeket felvevő és betöltő személyeket, mely kontinuum két végén az elkövető és az áldozat helyezkedik el. Ha a zaklató szerepétől indulunk el, akkor őt követik a csatlósok, akik a zaklatás aktív támogatói, de maguk soha nem kezdeményeznek. Utánuk jönnek a passzív zaklatók, akik pusztán helyeslő hozzászólásokkal tarkítják az agresszív viselkedést. E passzív támogatók azok, akik ugyan élvezik a zaklatást, de nem támogatják azt. Nagyjából középen helyezkednek el a szemlélők, akik állásfoglalás nélkül figyelik az eseményeket. A passziv védelmezők ellenzik a zaklatást, mégsem lépnek közbe, míg az aktív védelmezők minden lehetséges módon igyekeznek meggátolni azt.

Domonkos-Ujhelyi (2015): i. m. 78.

Frisén - Jonsson - Persson (2007): i. m. 
Jellemző rájuk a morális érzelmek (empátia) magas szintje, az erőteljesen funkcionáló én-hatékonyság, a felsőbb szociális státusz, az altruizmus és a proszocialitás, az adaptív megküzdési stratégiák megléte és alkalmazása. ${ }^{22}$

Kutatásokat elemezve „az a kép körvonalazódott, hogy a zaklatások gyakoriságát befolyásolhatja a szemlélők reakciója, vagyis a segítők részvétele a bántalmazásban, a védelmezők közbelépése és általánosságban a közösség reakciója. Egyrészt a szemlélők hatékonyak lehetnek a bántalmazás leállításában [...], másrészt a zaklatás az esetek 85-90\%-ában a kortársak jelenlétében zajlik, tehát a szemlélők szinte minden esetben jelen vannak a zaklatáskor" ${ }^{23}$

Jól látjuk tehát, hogy a zaklatás folyamatában nem pusztán az elkövető-áldozat szerepkör betöltőit kell azonosítani, hanem a csoportszerepek többi tagját is, hiszen az intervenció szempontjából nekik is óriási szerepük lesz a folyamat kezelésében.

A közbelépés elmaradásának oka lehet a zaklatótól, valamint az áldozattá válástól való félelem, a bizonytalan interperszonális kapcsolatok, ugyanakkor a fiatalabb csoportokban a zaklató egy idő után követendő modellé válhat. Bandura szociális tanuláselméletében a modell szerepe igen jelentős. Ha a modell szabadon cselekszik, tehát viselkedése nem kontrollált, vagy a viselkedését - legyen az akár proszociális, akár antiszociális - pozitív megerősítés követi, az általa tanúsított viselkedés követendő példává válik. Ellenkező esetben: ha a nemkívánatos viselkedésre negatív válaszreakció érkezik, akkor a nemkívánatos viselkedés ellenkezője fog a „tanuló” viselkedésében reprezentálódni. Ahhoz, hogy a modellel a gyermek azonosulni tudjon, az alábbi feltételek szükségesek:

- a modell és a megfigyelő között hasonlóság álljon fenn;

- a modell társadalmilag elfogadott szerepet töltsön be;

- a modell viselkedését jutalmazzák vagy legalábbis ne büntessék.

\section{Pszichés funkcióvesztés}

A zaklatások következményeivel a fiatalok nem mindig számolnak. Nincsenek vele pontosan tisztában, hogy az általuk elkövetett cselekedet milyen hatást vált ki az áldozatból. Ezek a következmények éppúgy lehetnek mentális jellegú (például stressz, szorongás, krónikus depresszió), mint testi tünetek (például emésztőrendszeri és kardiológiai problémák), amelyek kölcsönösen hatnak egymásra, interakcióban állnak. Kutatók elsőként a depresszív szimptómákat hozták kapcsolatba a cyberbullying jelenségével: szignifikánsan magasabb depressziós tüneteket detektáltak azoknál a fiataloknál, akik internetes zaklatásnak voltak kitéve. Természetesen a hatások nem pusztán lelki-fizikális diszfunkciók lehetnek: azok a gyerekek, akik a világhálón különböző negatív eseményeknek voltak kitéve, a későbbiekben roszszul múködő szociális kompetenciákkal rendelkeztek és kevésbé tudtak sikeresen reflektálni önmagukra. ${ }^{24} \mathrm{~A}$ pszichológiai „distressz”-állapotra adott válasz Schneider 
és munkatársai szerint ${ }^{25}$ lehet a teljesítmény drasztikus romlása, az alacsony iskolai elköteleződés, az önkárosítás vagy akár öngyilkosság elkövetése.

Hinduja és Patchin tanulmányukban ${ }^{26}$ azt írják, hogy a mindennapi zaklatás megtapasztalása az iskolában vagy annak környezetében jelentős mértékben összefügg az öngyilkossági képzetek egyre gyakoribb megjelenésével. Ugyanakkor kiemelik: nem pusztán az áldozatok, de az elkövetők körében is kockázatot jelent a szuicídium. Ok-okozati összefüggést tárnak fel a különböző viselkedéses komponensek között: a zaklatás által kialakult depressziós szimptómák - reménytelenség-érzés, elmagányosodás, egyre csökkenő önértékelés - mind prediktív tényezőként jelennek meg az öngyilkossági fantáziák kialakulása és gyakorivá válása során.

Vessünk külön pillantást a zaklatásokra adható extrém válasz, az iskolai ámokfutás meghatározására és kiindulópontjaira. A kriminológia a több ember sérelmére elkövetett életellenes bűncselekményeket négy kategóriában tárgyalja, a differenciálás szempontjai a következők: ${ }^{27}$

- ámokfutás: több helyszínen történő folyamatos elkövetés, az áldozatok személye kiszámíthatatlan és véletlenszerü; „rosszkor volt rossz helyen” - éppen akivel találkozik az elkövető (az egyes elméletek szerint ennek a típusnak az egyik altípusát adják a terroristatámadások); ${ }^{28}$

- tömeggyilkosság: ha egy helyszínen négy vagy több ember hal meg;

- sorozatgyilkosság: legalább három különböző időpontban kerül sor a cselekmények végrehajtására;

- kiterjesztett öngyilkosság (családirtás): egy alkalommal több ember életének kioltása.

Rátérve az iskolai ámokfutások áttekintésére: Mark Leary és munkatársai úgy gondolják, ${ }^{29}$ az egyre szélesebb körben és egyre gyakrabban megjelenő iskolai erőszak mögött a társadalom morális értékeinek hanyatlása áll. Elképzelésük értelmében a mai világ felértékeli a halál szerepét, az agresszív számítógépes játékok tárháza pedig végtelen. Összefoglalójuk szerint az iskolai ámokfutók - mint amilyen az 1999-es littletoni lövöldöző (Colorado, Egyesült Államok) volt - magányosak, társaiktól elszigetelten élik mindennapjaikat; osztálytársaiktól, iskolatársaiktól elutasítást kapnak; kívülállónak érzik magukat. Az állandó és ismétlődő zaklatás során elfojtott frusztrációjuk fokozódik, kifejeződése azonban gátlás alá kerül. Az elkövetők többsége azzal magyarázza tettét, hogy társai kiközösítették, bántalmazták őket, és csak a sérelmek miatt reagáltak extrém módon. Az egyik lövöldöző a vele készített interjúban azt mondja, azért ölt, mert mindennaposak voltak a megaláztatásai, és senkit nem érdekelt,

Schneider et al. (2012): i. m.

Hinduja-Patchin (2010): i. m.

Bolyky Orsolya: Az emberölések jogi és kriminológiai jellemzői, különös tekintettel a mentális tényezők büntetőjogi értékelésére. Doktori értekezés. Budapest, Pázmány Péter Katolikus Egyetem Állam- és Jogtudományi Kar, 2018.

28

Kulcsár Gabriella: Az iskolai ámokfutások etiológiája és a prevenció lehetőségei. Doktori értekezés. Pécs, Pécsi Tudományegyetem Állam- és Jogtudományi Kar, 2014; Katherine S. Newman: Rampage. The Social Roots of School Shooting. New York, Basic Books, 2004.

29 Mark R. Leary et al.: Teasing, rejection and violence. Case studies of the school shootings. Aggressive Behavior, 29. (2003), 202-214. 
hogy mi lesz vele. Vagyis az ámokfutást a társak felől érkező erőteljes szeparációs folyamat előzte meg.

Tanya Beran és Qing Li párhuzamot von az iskolai ámokfutások és az internetes zaklatás között. ${ }^{30} \mathrm{~A}$ társas csoportok, így az iskolai csoportok is hierarchikus szerveződést mutatnak, amelyben néhány csoporttag úgy próbál minél magasabbra jutni, hogy dominanciát gyakorol a többi tag felett. A dominancia kifejezésének módja sokféle lehet. Amikor ez a dominanciakifejezés olyan eszközöket hív segítségül, amelyek az individuum számára károsak - ilyen mondjuk az individuum életének külső kontrollálása -, akkor az egyén viselkedésmintázatába beemeli a cry for help reakciót. Ez egyfajta énvédő mechanizmusnak tekinthető; a személy külső segítségért kiált. Ha a segítség késve vagy egyáltalán nem érkezik meg, az egyén - jelen esetben a tanuló, diák - internalizálja a fokozott stresszhelyzet által kiváltottakat, például a stresszt, a magányosságérzést, a szomorúságot, ami életvitelére, teljesítményére és koncentrációs készségeire is negatív hatást fejt ki.

\section{Prevenciós lehetőségek}

Majd a tanár megoldja. Vagy: Ez az iskola feladata. Bizonyára sokak számára ismertek ezek a kijelentések. Ahogy minden iskolához kapcsolatos kötelezettséget, úgy a zaklatás kivédését, kiiktatását is sokan elsődegesen vagy akár kizárólagosan az intézmény feladatai közé sorolják. Pedig ez nem feltétlen van így. Természetesen elengedhetetlen a tájékozottság és tájékoztatás, ugyanakkor a közvetetten érintett képviselők (pedagógusok) helyett célszerübb a közvetlenül érintett csoportok (diákok) bevonása a prevencióba.

Domonkos szerint ${ }^{31}$ a megelőzés elsősorban az iskolapszichológus feladata. Meg kell ismertetni a diákokat a lehetséges beavatkozásokkal, ${ }^{32}$ és fel kell vértezni őket a szükséges tudással. Ennek eszköze lehet egy brosúra vagy az iskola által kialakított eljárási protokoll. Azonban nem minden intézményben dolgozik iskolapszichológus, ha mégis, elképzelhető, hogy egyszerre több iskolában lát el pszichológusi feladatkört, így nincs mindig „,helyben”, hogy azonnal reagálni tudjon az eseményekre. Körmendi ${ }^{33}$ az edukáció fontosságát emeli ki, amelynek „célközönségét” alkotják a diákokon túl a pedagógusok és a szülők is. Utóbbiak edukációja azért is fontos, mert a zaklatás különböző típusairól kevés információval rendelkeznek, mint ahogyan annak káros hatásairól is. A kívülállók pozitív megerősítéseit meg kell akadályozni a zaklató felé, ezek ugyanis facilitálják az ismételt cselekményt. A cél az kell legyen, hogy a kortársak beavatkozási lehetőségét emeljük ki, amihez a diákok edukációja

\footnotetext{
30 Tanya N. Beran - Qing Li: The Relationship between Cyberbullying and School Bullying. Journal of Student Wellbeing, 1. (2007), 2. 15-33. Domonkos (2014): i. m.

Mi az eljárás a nyílt, illetve a privát felületeken? Előbbi esetén az azonnali beavatkozás szükséges, míg az utóbbi esetben először a zaklató személyének figyelmen kívül hagyása javasolt mindamellett, hogy a zaklató tartalmakat mentsük le.

Körmendi (2014): i. m.
} 
szorosan kapcsolódik: hatékony kommunikációs technikák, megküzdési stratégiák oktatása segítően hathat.

Mind a prevenció, mind az intervenció szempontjából elengedhetetlen, hogy az iskolákban kialakítsanak egy széles körü, átfogó válaszstratégiát a bullyinggal szemben. Az igazságszolgáltatás nyújtotta eljárások mellett - polgári peres eljárás, büntetőeljárás, mediáció - az iskoláknak is ki kellene dolgozniuk egy iskolai protokollt, amelyben lefektetik az iskola zaklatással kapcsolatos vélekedését, illetve, hogy zaklatás esetén milyen szankciókat érvényesít az elkövetővel szemben az intézmény.

Fontos, hogy a prevenció célcsoportja ne csak az iskolában tanító pedagógus legyen: a zaklatás aktív és passzív résztvevőit is be kell vonni a megelőzésbe. A tanár nem tud mindig jelen lenni minden konfliktusnál, és ez nem is várható el tőle. Az online zaklatásnak pedig nem kritériuma, hogy iskolaidő alatt történjen meg. Véleményem szerint fontosabb, hogy a diákokra helyezzük a hangsúlyt, hiszen ők a folyamat aktív ágensei. Az edukációs elképzelés nagyon jó kiindulópont, amit érdemes lenne multidiszciplináris perspektívából megközelíteni.

Az egyik ilyen lehetőség egy face to face, formális oktatási forma. Ennek keretében alapvető jogi ismereteket kellene átadni és pszichoedukatív tevékenységet lehetne folytatni. Megismertetni a diákokat néhány alapvető büntetőjogi ténnyel, mint amilyen például a büntethetőség kérdése, és azzal, hogy bizonyos cselekedeteik esetleg kimeríthetik valamelyik büntetőjogi tényállást. A pszichoedukáció során a mentális jó- és jóllétről, a rezilienciáról, illetve az általánosan vett csoportdinamikai folyamatokról lehet érdemes párbeszédet folytatni, kiegészítve kommunikációs és asszertivitási tréningekkel, agressziókezeléssel.

A másik lehetőség olyan informális, aktív, csoportfoglalkozás-jellegú események szervezése, ahol a diákok játékos formában sajátítanak el egyes ismereteket és tapasztalatot szereznek.

Az online zaklatás elleni fellépés jól szervezett lehetősége a DGYS (Magyarország Digitális Gyermekvédelmi Stratégiája), amelyet a Kormány a szakmai és társadalmi szervekkel szorosan együttmúködve dolgozott ki. Mint fogalmaznak, a DGYS megalkotása során elsődleges szempont volt, hogy a fiatalok naprakész információ birtokába kerüljenek az internethasználat veszélyeit illetően, valamint, hogy felkészítsék a tanulókat, a szülőket és a tanárokat a tudatos és biztonságos internethasználatra. A DGYS keretében kidolgoztak egy kortárs segítő képzési rendszert is, aminek keretein belül az internet előnyeit, valamint annak kockázatait a leginkább érintettek számára a velük egykorú társaik prezentálják - ezáltal hitelesebbé válik az informátor és az általa közölt információ is.

Véleményem szerint a DGYS és az általa képviselt irány példaértékű és hiánypótló, ugyanakkor annak figyelembe kellene vennie azt is, hogy a cyberbullying nem korosztály-specifikus jelenség: a felnőttek körében éppúgy jelen lehet, mint a fiatalok esetében. Így célszerü lenne a DGYS mentén egy felnőttekre szabott, hasonló platform kidolgozása is. 


\section{Felhasznált irodalom}

Aricak, Tolga - Sinem Siyahhan - Aisegul Uzunhasanoglu - Sevda Saribeyoglu - Songul Ciplak - Nesrin Yilmaz - Cemil Memmedov: Cyberbullying among Turkish Adolescents. Cyberpsychology \& Behavior, 11. (2008), 3. 253-261. Online: https:// doi.org/10.1089/cpb.2007.0016

Bauman, Sheri - Russel B. Toomey - Jenny L. Walker: Associations among bullying, cyberbullying, and suicide in high school students. Journal of Adolescene, 36. (2013), 341-350. Online: https://doi.org/10.1016/j.adolescence.2012.12.001

Beran, Tanya N. - Qing Li: The Relationship between Cyberbullying and School Bullying. Journal of Student Wellbeing, 1. (2007), 2. 15-33. Online: https://doi. org/10.21913/JSW.v1i2.172

Bolyky Orsolya: Az emberölések jogi és kriminológiai jellemzői, különös tekintettel a mentális tényezők büntetőjogi értékelésére. Doktori értekezés. Budapest, Pázmány Péter Katolikus Egyetem Állam- és Jogtudományi Kar, 2018.

Calvete, Esther - Izaskun Orue - Ana Estévez - Lourdes Villardón - Patricia Padilla: Cyberbullying in adolescents. Modalities and agressors' profile. Computers in Human Behavior, 26. (2010), 1128-1135. Online: https://doi.org/10.1016/j. chb.2010.03.017

Domonkos Katalin: Cyberbullying: zaklatás elektronikus eszközök használatával. Alkalmazott Pszichológia, 14. (2014), 1. 59-70.

Domonkos Katalin - Ujhelyi Adrienn: Az online zaklatás médiareprezentációja. Neveléstudomány, (2015), 1. 77-92.

Frisén, Ann - Anna-Karin Jonsson - Camilla Persson: Adolescents' perception of bullying: Who is the victim? Who is the bully? What can be done to stop bullying? Adolescence, 42 (2007), 749-761.

Haller József - Fogarasi Mihály - Ivaskevics Krisztián: Agresszió és erőszakos bűncselekmények. In Haller József (szerk.): Büntettek kriminálpszichológiája. Budapest, Dialóg Campus, 2020. 17-58.

Hinduja, Sameer - Justin W. Patchin: Bullying, cyberbullying and suicide. Archives of Suicide Research, 14. (2010), 206-221. Online: https://doi.org/10.1080/138111 18.2010.494133

Körmendi Attila: A szemlélődők szerepe az iskolai zaklatásban. Alkalmazott Pszichológia, 14. (2014), 2. 105-121.

Kulcsár Gabriella: Az iskolai ámokfutások etiológiája és a prevenció lehetőségei. PhD-értekezés. Pécs, Pécsi Tudományegyetem Állam- és Jogtudományi Kar, 2014.

Leary, Mark R. - Robin M. Kowalski - Laura Smith - Stephen Phillips: Teasing, rejection and violence: case studies of the school schootings. Aggressive Behavior, 29. (2003), 202-214. Online: https://doi.org/10.1002/ab.10061

Newman, Katherine S.: Rampage. The Social Roots of School Shooting. New York, Basic Books, 2004.

Ortega-Ruiz, Rosario - Paz Felipe - Joaquín Mora-Merchán - Juan Calmaestra - Esther Vega: The emotional impact on victims of traditional bullying and cyberbullying. Journal of Psychology, 217. (2009), 4. 197-204. Online: https://doi. org/10.1027/0044-3409.217.4.197 
Schneider, Shari Kessel - Lydia O'Donnell - Ann Stueve - Robert W.S. Coulter: Cyberbullying, school bullying, and psychological distress. A regional census of high school students. American Journal of Public Health, 102. (2012), 1. 171-177. Online: https://doi.org/10.2105/AJPH.2011.300308

Vandebosch, Heidi - Katrien van Cleemput: Cyberbullying among youngsters. Profiles of bullies and victims. New Media \& Society, 11. (2009), 8. 1349-1371. Online: https://doi.org/10.1177/1461444809341263

Wölfner, R. -A. Schultze-Krumbholtz-P. Zagorscak-A. Jäkel-K. Göbel-H. Scheithauer: Prevention 2.0: Targeting Cyberbullying@School. Prevention Science, 15. (2014), 6. 879-887. Online: https://doi.org/10.1007/s11121-013-0438-y 